\title{
Comparison between Education and Tradition
}

\author{
Muslikhah, Ilva Maidia Wita, Eko Wanidison \\ Universitas Pendidikan Indonesia \\ Bandung, Indonesia \\ muslikhah@upi.edu, eko.wanidison@upi.edu, \\ ilvamaidia15@gmail.com
}

\author{
Nike Kamarubiani \\ Mass Education Departement \\ Universitas Pendidikan Indonesia \\ Bandung, Indonesia \\ nikekamarubiani@upi.edu,
}

\begin{abstract}
Tradition is a value and norm that has been passed down from ancestors to generations and must be continued to the next generation who live in the society, where the tradition is binding absolutely to the community. The purpose of this study was to find the changing tradition of Baduy Indonesia tribe due to the incoming education from the outside. This research used the descriptive qualitative method which chose Baduy Indonesia tribe from a west java as the sampling frame, it was chosen from the purposive sampling survey. The results of this study indicates that, in order to go to school, the children of Baduy tribe must be willing to bring their crops to be sold in the city, therefore they have the reason to get out of the village and go to study at school. The conclusion of this paper is education will not change the traditions of the Baduy tribe of Indonesia; with the education, people will be able to face the increasingly globalized world. The next generation of the tribe will not leave the village because they live and grow in the middle of custom rules and they will also keep the customary rules.
\end{abstract}

Keywords-Baduy Indonesia tribe; culture; comparative; correlation; development

\section{INTRODUCTION}

Tradition is a value and norm that has been passed down from ancestors to generations. It must be passed down continually to the next generation who live in the society where the tradition is absolutely binding to the community. Tradition is all things (such as customs, beliefs, customs, teachings and so on) that have passed from ancestor to generation [1]. Tradition also considered as a habit that becomes reflection to keep the identity of the tribe of Baduy people in Indonesia. Baduy tribe became one of the most popular ethnics in Indonesia due to the obedience they keep in maintaining the mandate of their ancestors. The simplicity of living life is a special attraction of Baduy Tribe where they deliberately alienate themselves from outside world (modernization); choosing their life to carry out the mandates of their ancestors. However, how long the Baduy tribe can still maintain the ancestral mandates in the midst of rapidly growing needs, changes and the current development of this era that cannot be avoided by the Baduy tribe?

Human creates traditions and cultures that made up the human characterization itself. Culture occupies a central position in the whole order of human life. The whole construction of human life and society stands on the foundation of culture [2]. Tradition is an act which done repeatedly in the same form [3]. The uniqueness of culture and customs that remain intact from the ancestors can still be found from the inland tribes in Indonesia, one of them is the Indonesian Baduy tribe in Banten Province. Baduy Indonesia is a name to mention the indigenous people in Banten Province. Baduy Indonesia consists of 3 (three) large groups of Baduy Dalam and 62 (sixty two) Baduy Luar tribe who are still under the leadership of Puun (Baduy Traditional Chief) scattered occupied the village in Banten Province.

The customs in Baduy tribe of Indonesia have regulated the life of its people from the mindset, beliefs, education, social relations, marriage and other small matters. The customs regulated in the customary law of the Baduy tribe of Indonesia. Speaking about education, Baduy Indonesia actually recognizes the nature of education related to the preservation of ancestral culture. Those ancestral culture such as/are the tradition that always maintained in the Baduy Indonesia tribe to preserve the cultural arts taught from generation to generation by the people in Baduy tribe, such as Angklung, Koromong (Jaipong), and Menenun. The people of Baduy Dalam tribe still do not want to receive treatment or medicine from outside, thus the people of Baduy Indonesia learned to mix the medicines from the forest plants from/through generation to generation. Some examples of commonly used plants by the Baduy community to treat minor ailments are: guava leaves to treat stomach pain, bitter jampang leaves to treat wounds, capeuk plants to relieve achy, harendong leaves to treat toothache, and terep skin tree to remove itching on the skin [4]. The largest category is nature and scenery (geysers, wild nature, scenery, volcano/ lava, waterfalls, mountains, glaciers, nature, water, clean, cold, skies) [5]. This is a proof that Baduy tribe kept the education from the ancestors, but they are not familiar with education as it is today. In Roman language, education is termed as 'educate' which means putting out something inside. In English, education is termed 'to educate' which means to improve morale and intellectual training [6]. Langeveld in Hasbullah [7] explains education is every effort, influence, protection, and assistance that are given to the child, more specifically, to the child's maturity, or rather helping the child to be adequately qualified to living the child's life. That influence comes from adults (or created by adults through school, books, daily life cycle, and others) and is shown to an immature person.

For people in Baduy Indonesia, education will only damage the customs order that has been intact for decades. Besides the natural education, Baduy Indonesia tribe does not recognize other education, such as reading, writing and counting which 
generally studied in schools. Up to these days, Baduy society still rejects the existence of formal education in ulayat land and prohibits their society to follow formal education. Formal education (school) is still considered as a taboo thing, especially for Baduy Dalam people who still adhere to the customary rules. The literature indicates a need for further examination of [8]. Thus, education is needed to support human life, and should be a sustainable education. That all 16 year olds would continue with education and / or training past the statutory school leaving age [9]. One of the interesting topics from Baduy tribe is the difference of perspective toward education. The perspective from Baduy chief and other figures about education is very diverse, yet they have not lead to same points of understanding; whether formal education (school) for Baduy society is a very taboo thing? Is the existence of formal education (school) in Baduy will be very harmful and damage the future of Baduy society? If school is taboo things, why many people of Baduy tribe are skillfully read, write, count, have the ability to communicate, interact, and even have a wide business network? If schooling is prohibited, why those active and creative people are able to learn, read, write and count without sanctions? [4].

Based on the description of the research background, this research problem can be formulated as follows: is it true that education will change the tradition of Indonesian Baduy? With the aims of this research:(1) to know the change in traditions of Indonesian Baduy tribe due to education coming from outside; (2) To know the change in traditions of Indonesian Baduy people due to the development of the era.

\section{LITERATURE REVIEW}

Education is a system that affects, and / or is influenced by other living systems that occur outside the education system [10]. Throughout the world, people are looking to education to pave the way for a more just social order on the grounds that education instills in the young crucial humanitarian values such as equity, tolerance and peace [11]. The existence of education itself will change the society from the mindset, habits, technological advances, and the increase of life. Thus, people can solve their problem of life by themselves. It affects and effects on society through shocking events and eventually changethe society [12]. Some researchers have indicated that children with a positive development of social competence may have good relationship with their friends and adult they can cooperate with others, deal with conflict properly, and have a capacity of probelm solving [13].

Humans are people who have perfect minds and dignities that settled their life and gathered to form a society. According to koentjaraningrat [14], society is the unity of human's life that interacts according to a system of certain customs that are continuously bound by a sense of common identity. Meanwhile Shadily [15] states that society is a group of people who live together in a place that is set with certain bonds and rules. In some sense, the narrative of leaving home produces [16]. Hence, society is a group of people who interact in one unity that occupies a place with binding rules.

Baduy Indonesia tribe also has custom rules that bind every member of the community. It also arrange every activities of the society. Traditional rules in the Baduy Indonesia tribe bind members of the community in the customary law of the tribe Baduy Indonesia. As culture plays a significant role in the restructuring of an urban economy and identity, an increasing literature emerges on culture-led regeneration in the cities of the developed world [17].

Through the above situations, a framework designed to deepen the understanding of this research. The framework is:

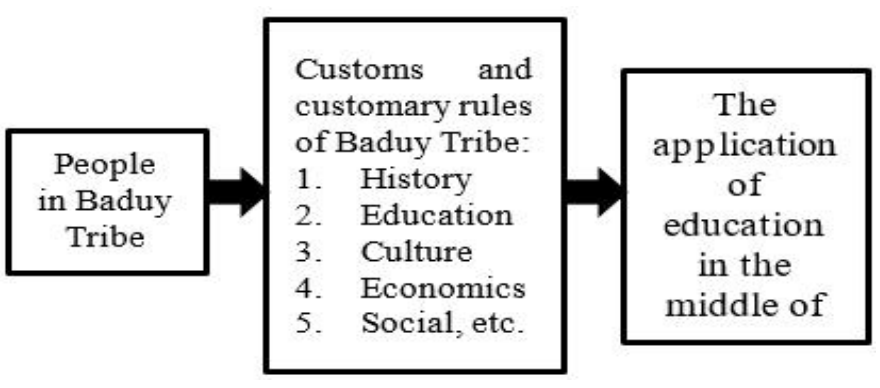

Fig. 1. Framework designed.

\section{METHOD}

This research was conducted in Cikeusik village of Pandeglang regency, Banten province in November 2017. The selected village was chosen because the people in Baduy Indonesia tribe is still running local wisdom of their predecessor in Baduy tribe. The type of research was field research, while the research method that used was qualitative research because the research problems were holistic, complex, dynamic and full of meaning. The researchers tried to deepen understanding on the social meanings that emerge in the environment of the research object, find patterns, and hypothesis by using theories to study the object of research [18].

This research used descriptive qualitative method with purposive sampling. The participants of this study were 5 persons from the Cikeusik tribe community. The participants' were as follows: ST is a society of Baduy tribe, SR is the educator of Baduy Luar community, IW is the manager of PKBM Kencana Ungu, SI and AT is a student at PKBM Kencana Ungu. SR and IW participations were used as primary data while ST, SI and AT participations were used as secondary data

The data were collected through interview and observation. The data in this study were collected by using several instrument tools, including interviews guides, observation sheets, and documents, and making notes from the result of interviews, observations, and documents analysis.

This research used an inductive approach with an interactive model as the data analysis. The process of qualitative analysis in this study had 4 important components, including; data collection, data reduction, data display, and data conclusion and verification. 


\section{RESULTS AND DISCUSSION}

Cikeusik Village is one of the villages in Cikeusik subdistrict, Pandeglang District, Banten Province. The village is located $\pm 20 \mathrm{~km}$ from the sub-district capital of Cikeusik and \pm $120 \mathrm{~km}$ from the district capital of Pandeglang. With an area of +35 sq. km, Cikeusik Village is one of the villages occupied by the people of Baduy Dalam besides Cibeo village and Cikartawarna village. Baduy tribe is divided into 3 major tribes, namely Cikeusik, Cibeo and Cikartawarna. The focus of the research was conducted on Baduy Cikeusik tribe because the customs' tribe is still very strong and has not been affected by the civilization from the outside world.

Baduy Dalam Cikeusik tribe can be reached by the land route with walking around $\pm 15 \mathrm{~km}$ and \pm 1 hour trip of riding public transportation (angkot) from the Baduy Luar tribe to the entrance of the tribe Baduy Dalam. Baduy Dalam tribe cannot be crossed by vehicle due to the local custom rules. All of the electronics should also be turned off from the entrance gate of Baduy Cikeusik tribe because they do not allow electronic devices to enter the region. The path that must be passed was quite difficult because we went to the forest that has been opened for farming or berhuma (as people of Baduy tribe often the call it). The still-ground path has not yet had a touch of development giving it so much nuance as maintaining local wisdom by utilizing the natural prosperity to survive. Demographically, the inhabitants of Baduy Dalam village have eyes as farmers. All the Baduy communities are farmers of dry rice (huma) with shifting cultivation system [19]. They farm in the field of plantation by clearing forestland such as planting rice or corn. The rice production of Baduy community to supply its basic need is generally insufficient [20] with the population of 3 kampung of Baduy tribe is 1300 people. Most of the Baduy Luar people have job as a farmer $(98.6 \%$ for husband and $90.7 \%$ for wife) [21].

The adopted religion by the people of Baduy tribe is Sunda Wiwitan (original religion of the tribe Baduy). According to the of Baduy tribe people, Sunda wiwitan religion has existed from the Padjajaran era. The villagers of the Baduy Cikeusik tribe adhere the values they believe from their ancestors and they also want to be educated by formal institution, such as school. These can present problems to be solved, allow exploration of a model of some aspect of our world, invite collaboration, role play and soon [22]. Such studies tend to generate answers that reinforce people's social identities [23]. Is it true that education will change the customs?

The custom values that are still maintained today are:

- Kungkurungan (Keeping and preserving the Environment)

- Rerongan (Gotong Royong/ cooperate in share-work)

- Trust with other forces

- Adoption of customary law

- The role of leader in decision making

These five custom values are the ancestral values that preserved to this day in Baduy Tribe. At the first time, Baduy tribe was named "Tantu telu jaro tujuh" not Baduy Tribe. Due to the region that surrounded by the mountain, Tantu telu jaro seven eventually changed the name to Baduy tribe. The tribe still maintain and preserve nature by utilizing nature in accordance with the needs that needed by the community without destructing it by excessive use. Baduy tribe has the principle of "gunung teu meunang dilebur, lebak teu meunang dirusak, larangan teu meunang dirobah, lojor teu meunang di potong, pondok teu meunang disambung, nu lain kudu dilainkeun, nu ulah kudu dulahkeun, nu enya kudu dienyakeun". With the meaning of the mountain should not be destroyed, the valley should not be destroyed, the prohibition should not be broken, the greatest should not be changed, the length should not be cut, the short should not be spliced, which should not be eliminated, which should not be denied, which must be justified. On the other hand there are symptoms of the destruction of isolated communities ethics under the pretext of environmentally friendly development that comes from inside and outside [24].

According to Mr. SR, Baduy tribe does not use nature for private property; nature will provide what they need. Baduy Dalam tribe do not use nails or tools from outside to make the house, they only use rattan and other materials from nature. It is different with the Baduy Luar tribe who already use the materials from the outside of Baduy to fulfil the needs of the community. Baduy Luar tribe is still bound by the rules of the tribe of Baduy Dalam, but Baduy Luar people are willing to accept the change. The people of Baduy Luar Cikeusik have started to have a livelihood of trading and weaving. There are some people who also have mobile phones but for formal education, and it cannot be used in Baduy tribe because there will be firm sanctions later. Every individual is born with the ability to speak [25]. There are concerns from the Puun (Baduy Customary Chief) about the education for younger generation; they will leave the tradition of their ancestors. Mores as part of local wisdom still be holder firm considerably by society Baduy, and the mores have come to the self fortress for society Baduy in face of modernization, included in matter preserve its environment [26].

However, due to the children's desire and passion to learn, I support them by asking PKBM Kencana Ungu as the media or place to study the children of Baduy tribe. Literacy acquisition is approached as a process of socialization situated in the context of the power structures of society and institutions [27]. The children of Baduy tribe can still follow and go to this nonformal school because there are no rules for uniform and schedule to enter the school every day like a formal school. There are 20 children of Baduy Luar tribe who began to study in PKBM Kencana Ungu. Children Baduy tribe must be willing to bring the crop to be sold in the city, therefore they have the reason to get out of the village and go to school.

IW also added that the spirit of children Baduy tribe should get the attention from the government, thus the children from Baduy tribe can get a decent education. AT is a child of the Baduy Luar Cikeusik tribe who went to PKBM Kencana Ungu. The child said that, at least I can read and count, so I will not to be easily deceived by people, and not strayed away when I go out. SI also added recognition, that education will not change the tradition and we will not leave the village because our family is here and we are comfortable living here. 
Gotong-royong conducted by Baduy tribe once in a month to jointly improve and keep the village infrastructure stay as firm as it should be with the collected funds of the residents. The maintenance is done only once in a month because they use bamboo for the damages' replacement.

Customary law for Baduy people is one of the media to create compliance in preserving the custom values. Customary law itself is binding for its members to regulate the life of the community. The examinations were not exactly the same between sections [28]. The highest customary law in Baduy tribe is governed by Puun (customary chief of Baduy), below the Puun, there is Jaro Tangtu (vice Puun), assisted by Tangsungan (reliable person), Tangkesa (Local Government), and Jaro Tujuh (head of the neighborhood). Every policy and rule will be discussed carried out in a deliberative manner. Every decision that has been made cannot be contested and is absolute to its members. Mr. SR has a view that "Education existing in the Baduy tribe society is an education that inherits indigenous knowledge". It is understandable from that opinion that in Baduy society, the most important and foremost education for its people is education on indigenous knowledge. Indigenous knowledge is a form of knowledge that cannot be found in formal education. The education system in Baduy society is an adapted education system for the customary mandates which become the main foundation of the education system in Baduy society. As in the proverbs of Baduy society, " Lojor teu beunang dipotong, Pondok teu benang disambung, Gede teu benang dicokot, Leutik teu beunang ditambah" means that what already exists and become the mandate of ancestors in Baduy people life must be obeyed with the principle of life in accordance with the applicable rules since their tribal civilization was born. The applied model or form of education in Baduy society is hereditary with oral and direct practice. The common and general knowledge they get is in the form of spells for traditional ceremonies or plant rice, craft making skills, and so forth.

\section{CONCLUSION}

Baduy Tribe Indonesia is one of the indigenous tribes in Indonesia who still keep the local wisdom that shows the original values of indigenous mutual care and preserve nature for the importance of the village. It can be seen that education is in line with tradition. Education will not change the traditions of the Baduy Indonesia tribe; with the education, people will be able to face the progress of time. The next generation of the tribes will not leave the village because they live and grow in the custom rules to keep the customary rules. The children who have passed Equivalency Examination in PKBM Kencana Ungu do not leave the Baduy tribe of Indonesia and remain compliant to the customary rules. Education has actually been internalized through the traditions that they have been holding until now. Baduy tribe is one proof that the changing era, local wisdom will make people friendly and presere to nature. With the consciousness or not, Baduy tribe is a tribe that need to be preserved to show so beautifully religious.

\section{ACKNOWLEDGEMENTS}

We would like to acknowledge several parties that support the completion of the paper, i.e. Lembaga Pengelolaan Dana Pendidikan (LPDP) for sponsoring and Dr. Nike Kamarubiani, M.Pd. for guiding the researchers throughout the research process.

\section{REFERENCES}

[1] Poerwadarminto, W., J., S. Kamus umum bahasa indonesia. Jakarta: Balai Pustaka, 1976.

[2] Raga, M., R. Manusia dan kebudayaan dalam perspektif ilmu budaya dasar. Jakarta: Rineka Cipta, 2000.

[3] Soekanto, Soejono. Sosiologi suatu pengantar. Jakarta: Rajawali Pers, 1990.

[4] Kurnia, A. and Sihabudin, A. Saatnya baduy bicara. Jakarta: Bumi Aksara. 2009.

[5] Gudlaugsson, T., and Magnu'sson, G., Emerald Article: North Atlantic island destinations in tourists' minds. International Journal of Culture, Tourism and Hospitality Research, 6 (2), 114 - 123. ISSN 1750-6182. 2012.

[6] Kadir, A, Dasar-dasar pendidikan. Jakarta: Kencana Prenada Media Grup. 2012.

[7] Hasbullah. Dasar-dasar ilmu pendidikan, Jakarta: PT Grafindo Persada. 2009.

[8] Durmaz, B., Platt, S., and Yigitcanlar, T. Creativity, culture tourism and place-making: Istanbul and London film industries. International Journal of Culture, Tourism and Hospitality Research, 4 (3), 198-213. 2010.

[9] Gulam, W., A., Ahmed, J., and Wilkinson, V. Student life and tribulations in the Midlands. Journal of Educational Research,10 (2), 316. ISSN: 1027-9776, 2007.

[10] Suryadi, A., and Budimansyah, D. Paradigma pembangunan pendidikan nasional. Bandung: Widya Aksara Press, 2009.

[11] Serbessa, D., D. Tension between traditional and modern teachinglearning approaches in ethiopian primary schools. Journal of International Cooperation in Education, 9 (1), 123-140. 2006.

[12] Piotr, S. Sosiologi perubahan sosial. Jakarta: Prenada, 2004.

[13] Iswinarti, Endang, E., Adiyanti, M.,G., and Rahmat. The influence of traditional game with experiential learning method on social competence. International Journal of Recent Scientific Research , 7 (4), 10147-10155, ISSN: 0976-3031, 2016.

[14] Koentjaraningrat. Pengantar ilmu antropologi. Jakarta: Aksara Baru, 1985.

[15] Shadily, H. Sosiologi untuk masyarakat indonesia. Jakarta: Bina Aksara, 1984.

[16] Ahmed, S. Home and away: narratives of migration and estrangement. International Journal of Cultural Studies, 2 (3), 329-347. 1999.

[17] Gezici, F., and Kerimoglu, E. Culture, tourism and regeneration process in Istanbul. International Journal of Culture, Tourism and Hospitality Research, 4 (3), 252 - 265. 2010.

[18] Sugiyono. Metode penelitian pendidikan pendekatan kuantitatif, kualitatif, dan R\&D. Bandung: Alfabeta, 2011.

[19] Senoaji, G. Masyarakat Baduy, Hutan, dan lingkungan. Jurnal Manusia dan Lingkungan, 17 (2), 113-123. 2010.

[20] K. Ali, and W. Wigna. Sosio-Budaya Pangan Suku Baduy. Jurnal Gizi dan Pangan 4. 2, 2009. 63-71.

[21] S. Dadang, and E. S. Mudjajanto, "Kebiasaan Dan Konsumsi Pangan Suku Baduy." Jurnal Gizi dan Pangan 4. 2, 2012: 51-62.

[22] Allsop, Y., Jessel, J., and Goldsmiths. Teachers' experience and reflections on game- based learning in the primary classroom: views from England and Italy. The International Journal of Game-Based Learning, 5 (1), 1-17. ISSN 2155-6849, eISSN 2155-6857, 2015.

[23] Deuze, M. Convergence culture in the creative industries. International Journal of Cultural Studies, 10(2), 243-263. 2007. 
[24] Suhadi. Etika Masyarakat Baduy Sebagai Inspirasi Pembangunan. Jurnal Komunitas, 4 (1), 65-72. 2012.

[25] Kirbaş, A. Effects of cooperative learning method on the development of listening comprehension and listening skills. International Journal of Languages' Education and Teachin, 5 (1), 1-17. 2017.

[26] Suparmini, Sriadi Setyawati, Dan Dyah Respati Suryo Sumunar. Pelestarian Lingkungan Masyarakat Baduy Berbasis Kearifan Lokal. Jurnal Penelitian Humaniora, 18 (1), 8-22. 2013.
[27] Rutten, K., Rodman, G., B., Wright, H., K., and Soetaert, R. Cultural studies and critical literacies. International Journal of Cultural Studies, 16 (5), 443-456. 2013.

[28] Steven Stack, Dr., Learning Outcomes in an online vs traditional course. International Journal for the Scholarship of Teaching and Learning, 9 (1), 1-15. 2015. 